\title{
Carbon sequestration within millet phytoliths from dry-farming of crops in China
}

\author{
ZUO XinXin ${ }^{1,2^{*}} \&$ LÜ HouYuan ${ }^{1}$ \\ ${ }^{1}$ Key Laboratory of Cenozoic Geology and Environment, Institute of Geology and Geophysics, Chinese Academy of Sciences, Beijing 100029, \\ China; \\ ${ }^{2}$ Graduate University of Chinese Academy of Sciences, Beijing 100049, China
}

Received April 28, 2011; accepted July 8, 2011; published online August 30, 2011

Phytoliths are noncrystalline minerals that form inside cells and cell walls of different parts of plants. Organic carbon in living cells can be occluded in phytoliths during plant growth. It has been documented that the occluded carbon within phytoliths is an important long-term terrestrial carbon reservoir that has a major role in the global carbon cycle. Common millet and foxtail millet have become typical dry-farming crops in China since the Neolithic Age. The study of carbon conservation within phytoliths in these crops could provide insights into anthropogenic influences on the carbon cycle. In this study, we analyzed the carbon content in phytoliths of common millet and foxtail millet. The results indicated that (1) common millet and foxtail millet contained $0.136 \% \pm 0.070 \%$ and $0.129 \% \pm 0.085 \%$ phytolith-occluded carbon (PhytOC) on a dry mass basis, respectively; (2) based on the mean annual production of common millet and foxtail millet in the last 10 years, the phytolith occluded carbon accumulation rate of common millet and foxtail millet was approximately $0.023 \pm 0.015$ and $0.020 \pm 0.010 \mathrm{t} \mathrm{CO}_{2} \mathrm{ha}^{-1} \mathrm{a}^{-1}$, respectively; (3) assuming a similar phytolith occluded carbon accumulation rate as for common millet (the highest accumulation rate was $0.038 \mathrm{t} \mathrm{CO}_{2} \mathrm{ha}^{-1} \mathrm{a}^{-1}$ ), this could result in the sequestration of $2.37 \times 10^{6} \mathrm{t} \mathrm{CO}_{2}$ per year for the $62.4 \times 10^{6}$ ha dry-farming crops in China. Although there was a decline in the annual production rate and planting area of foxtail millet during 1949 to 2008 , the total phytolith carbon sequestration rate was $7 \times 10^{6} \mathrm{t} \mathrm{CO}_{2}$ within the 60 -year period. However, phytolith occluded carbon has not yet been fully considered as a global carbon sink. Also, this carbon fraction is probably one of the best candidates for the missing carbon sink.

phytoliths, carbon sequestration, dry-farming, phytolith occluded carbon, PhytOC

Citation: Zuo X X, Lü H Y. Carbon sequestration within millet phytoliths from dry-farming of crops in China. Chinese Sci Bull, 2011, 56: 3451-3456, doi: $10.1007 / \mathrm{s} 11434-011-4674-\mathrm{X}$

The carbon cycle plays a central role in global change and its importance has already been recognized by the International Geosphere-Biosphere Programme (IGBP) [1-4]. There is an imbalanced budget (or some missing carbon) in the carbon cycle which has been known for nearly half-century, however, the mechanism for (and distribution of) this carbon has not yet been identified completely [5-8]. Many previous studies have suggested that terrestrial ecosystems in the mid- and high-latitudes of the Northern Hemisphere might be functioning as a significant carbon sink [9-11]. The pedosphere, a part of terrestrial ecosystems, contains a

*Corresponding author (email: zuoxinxin@live.cn) large amount of carbon, that is about $1550 \mathrm{Pg}$ carbon in soil inorganic matter and $950 \mathrm{Pg}$ carbon in soil organic matter. A minor variation in such big carbon pool may have a significant effect on the carbon sink [12]. Consequently, the soil was recognized as a probable candidate for the location of the missing carbon sink [13], and thus a greater understanding of its carbon pools has increased our knowledge of the importance of this part of the carbon cycle.

Phytoliths, also called silica phytoliths, are noncrystalline minerals that deposit inside cells and cell walls of different parts of plants when soluble silica is absorbed by the roots $[14,15]$. Phytoliths can occlude some organic carbon (phytolith occluded carbon (PhytOC)) incorporated during plant 
growth [16]. When plants die and decay, phytoliths are released into the soil and sediment. PhytOC can remain in the soil for a long time even being present in Tertiary [17] and Late Cretaceous sediments [18]. Recent studies indicate that PhytOC from bamboo vegetation globally could sequester $15.6 \times 10^{6} \mathrm{t}$ of $\mathrm{CO}_{2}$ per year. These authors argued that if all $4.1 \times 10^{9}$ ha of potentially arable land was used to grow bamboo, the global potential for phytolith carbon sequestration was $1.5 \times 10^{9} \mathrm{t} \mathrm{CO}_{2} \mathrm{a}^{-1}$. This carbon sequestration rate could therefore account for $11 \%$ of the current increase in atmospheric $\mathrm{CO}_{2}$ [19]. PhytOC is a recalcitrant fraction of soil carbon [20] which has drawn particular attention from many researchers in the study of the terrestrial carbon cycle [21].

Early studies have analyzed the physical and chemical properties of phytoliths and found that they can occlude carbon to levels ranging from $0.2 \%$ to $5.8 \%$ [22-25]. Current studies on phytoliths have mainly concentrated on the paleoclimate [26-29], archaeobotany [30-32], radiocarbon AMS measurements [23,24], carbon isotopes [33-35] and plant taxonomy [36,37]. However, far fewer studies have examined the PhytOC content of different plants. Although there already have been some studies on the PhytOC content of bamboo and sugarcane $[19,38]$, to date, very little is known about other higher silicon accumulating plants, such as Sorghum bicolor, Oryza sativa, Panicum miliaceum and Setaria italica.

Previous research has claimed that the carbon sequestered by crops in the form of PhytOC was considered as zero because the litter decayed and decomposed quickly [39]. As China has a long farming history and a large area of arable land, it is necessary to further explore the importance of PhytOC which may help to identify agricultural carbon sinks in the past and re-evaluate the carbon sink potential of current agricultural land. This study aims to (1) examine the PhytOC content of foxtail millet and common millet, (2) estimate the PhytOC accumulation rate of foxtail millet and common millet, and (3) estimate the amount of carbon sequestered by PhytOC from dry-farming crops in China.

\section{Materials and methods}

In this study, eight millet species, including foxtail millet
(Setaria italica) and common millet (Panicum miliaceum), were collected from Beijing, Gansu and Liaoning provinces during the harvest season (Table 1). The root of the millet was discarded and rest of the plant such as the stem leaf and spike were placed in a beaker for further treatment. All of the millet samples were rinsed twice in distilled water and placed in an ultrasonic bath for $20 \mathrm{~min}$, and then dried at $70^{\circ} \mathrm{C}$ for $24 \mathrm{~h}$. Four parallel samples were selected from each species of millet.

The method for phytolith extraction was described in detail in previous work $[15,40]$. In this study, a revision to the wet oxidation method was made that aimed to digest the organic matter more completely. The detailed steps are as follows: (1) Weigh about $1 \mathrm{~g}$ dry sample into a tube (to the nearest $0.01 \mathrm{mg}$ ); (2) add $5 \mathrm{~mL} \mathrm{HNO}_{3}$ into the tube and heat in a water bath at $80^{\circ} \mathrm{C}$ until reaction stops, then centrifuge 2 times at $3000 \mathrm{r} / \mathrm{min}$ for $5 \mathrm{~min}$ and decant supernatant; (3) add $10 \% \mathrm{HCl}$ into a tube and heat in a water bath at $80^{\circ} \mathrm{C}$ for $30 \mathrm{~min}$, then centrifuge at $3000 \mathrm{r} / \mathrm{min}$ for $5 \mathrm{~min}$ and decant; (4) add $5 \mathrm{~mL} \mathrm{HNO}_{3}$ into the tube and heat to ensure removal of all organic material, then centrifuge and decant; (5) add $5 \mathrm{~mL} \mathrm{H}_{2} \mathrm{SO}_{4}$ into the tube and heat in a water bath for at least $1 \mathrm{~h}$; (6) cool to room temperature, and reheat in a water bath, and add $30 \% \mathrm{H}_{2} \mathrm{O}_{2}$ slowly until the liquid clears; and (7) centrifuge 4 times at $3000 \mathrm{r} / \mathrm{min}$ for $5 \mathrm{~min}$, then dry phytoliths in the tube at $70^{\circ} \mathrm{C}$ for $24 \mathrm{~h}$.

Weigh the phytoliths using an analytical balance and check the samples under an optical microscope at $400 \times$ magnification to ensure no organic material exists. As Figure 1 shows, all the organic material has been digested. The PhytOC content was determined using an Elemental Analyzer vario EL (Elementar Analysen systeme GmbH, Germany).

\section{Results}

As shown in Table 2, the millet phytolith content varied from $3.027 \%$ to $18.787 \%$. The PhytOC content of millet also show a significant variation which ranged from $0.88 \%$ to $4.775 \%$. Common millet yielded a higher mean value of PhytOC content than foxtail millet phytolith content $(2.51 \%$ vs. $1.920 \%$ ). The relationship among PhytOC content on a dry weight basis, the occluded carbon of phytoliths and phytolith content was examined. The results indicated that

Table 1 Location and samples for each millet species

\begin{tabular}{lll}
\hline Sample code & \multicolumn{1}{c}{ Millet species (breed) } & \multicolumn{1}{c}{ Location } \\
\hline GSFM & Setaria italica Gansu & Xifeng District, Gansu Province \\
LNFM-A & Setaria italica Liaoning A & Suizhong County, Liaoning Province \\
LNFM-B & Setaria italica Liaoning B & Suizhong County, Liaoning Province \\
BJFM & Setaria italica Beijing & Mengtougou District, Beijing \\
GSCM-A & Panicum miliaceum Gansu A & Xifeng District, Gansu Province \\
GSCM-B & Panicum miliaceum Gansu B & Xifeng District, Gansu Province \\
LNCM & Panicum miliaceum Liaoning & Suizhong County, Liaoning Province \\
BJCM & Panicum miliaceum Beijing & Mengtougou District, Beijing \\
\hline
\end{tabular}




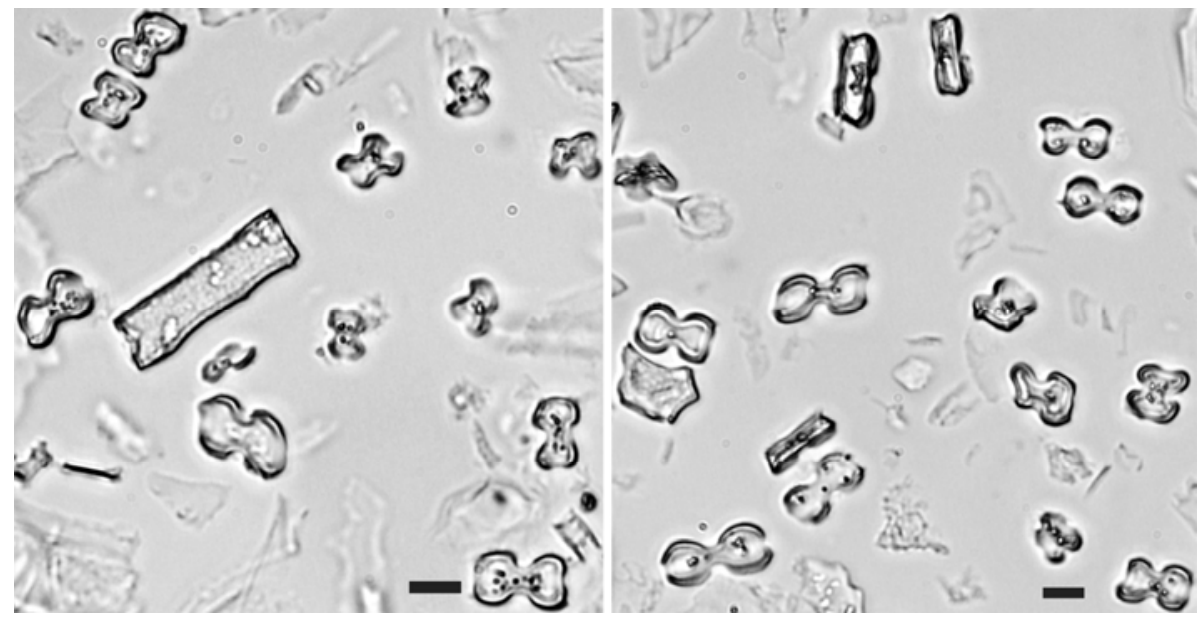

Figure 1 Phytoliths extracted from the millet samples (Both are from foxtail millet and black bar represents $10 \mu \mathrm{m}$ ).

Table 2 Dry weight, plant phytolith content, percentage phytolith content, percentage of PhytOC, and percentage PhytOC content on a dry weight basis

\begin{tabular}{|c|c|c|c|c|c|}
\hline Sample code & $\begin{array}{l}\text { Dry weight } \\
(\mathrm{g})\end{array}$ & $\begin{array}{l}\text { Phytolith content } \\
\text { in plant }(\mathrm{g})\end{array}$ & $\begin{array}{l}\text { Percentage of phytolith } \\
\text { content }(\%)\end{array}$ & $\begin{array}{l}\text { Percentage of PhytOC } \\
\text { in phytoliths }(\%)\end{array}$ & $\begin{array}{l}\text { Percentage of PhytOC } \\
\text { content/dry weight (\%) }\end{array}$ \\
\hline GSFM-1 & 1.079 & 0.049 & 4.541 & 4.775 & 0.217 \\
\hline GSFM-2 & 1.075 & 0.058 & 5.395 & 2.085 & 0.112 \\
\hline GSFM-3 & 1.051 & 0.063 & 5.994 & 2.59 & 0.155 \\
\hline GSFM-4 & 1.040 & 0.042 & 4.038 & 4.605 & 0.186 \\
\hline LNFM A-1 & 1.035 & 0.065 & 6.280 & 1.03 & 0.065 \\
\hline LNFM A-2 & 1.014 & 0.065 & 6.410 & 1.17 & 0.075 \\
\hline LNFM A-3 & 1.010 & 0.060 & 5.941 & 1.005 & 0.060 \\
\hline LNFM A-4 & 1.033 & 0.065 & 6.292 & 0.97 & 0.061 \\
\hline LNFM B-1 & 1.050 & 0.061 & 5.810 & 1.06 & 0.062 \\
\hline LNFM B-2 & 1.015 & 0.076 & 7.488 & 0.98 & 0.073 \\
\hline LNFM B-3 & 1.012 & 0.063 & 6.225 & 1.12 & 0.070 \\
\hline LNFM B-4 & 1.037 & 0.106 & 10.222 & 1.15 & 0.118 \\
\hline BJFM-1 & 1.058 & 0.094 & 8.885 & 0.94 & 0.084 \\
\hline BJFM-2 & 1.004 & 0.142 & 14.143 & 0.88 & 0.124 \\
\hline BJFM-3 & 1.059 & 0.138 & 13.031 & 1.85 & 0.241 \\
\hline BJFM-4 & 1.073 & 0.086 & 8.015 & 4.515 & 0.362 \\
\hline Mean \pm SD & & $0.077 \pm 0.029$ & $7.419 \pm 2.860$ & $1.920 \pm 1.427$ & $0.129 \pm 0.085$ \\
\hline GSCM A-1 & 1.054 & 0.050 & 4.744 & 2.92 & 0.139 \\
\hline GSCM A-2 & 1.019 & 0.048 & 4.711 & 4.62 & 0.218 \\
\hline GSCM A-3 & 1.017 & 0.055 & 5.408 & 3.665 & 0.198 \\
\hline GSCM A-4 & 1.014 & 0.043 & 4.241 & 3.05 & 0.129 \\
\hline GSCM B-1 & 1.037 & 0.044 & 4.243 & 3.86 & 0.164 \\
\hline GSCM B-2 & 1.033 & 0.038 & 3.679 & 3.39 & 0.125 \\
\hline GSCM B-3 & 1.041 & 0.042 & 4.035 & 2.95 & 0.119 \\
\hline GSCM B-4 & 1.014 & 0.041 & 4.043 & 4.635 & 0.187 \\
\hline LNCM-1 & 1.022 & 0.192 & 18.787 & 1.45 & 0.272 \\
\hline LNCM-2 & 1.009 & 0.147 & 14.569 & 1.495 & 0.218 \\
\hline LNCM-3 & 1.015 & 0.058 & 5.714 & 1.815 & 0.104 \\
\hline LNCM-4 & 1.002 & 0.088 & 8.782 & 1.245 & 0.109 \\
\hline BJCM-1 & 1.024 & 0.031 & 3.027 & 1.345 & 0.041 \\
\hline BJCM-2 & 1.034 & 0.043 & 4.159 & 1.295 & 0.054 \\
\hline BJCM-3 & 1.020 & 0.034 & 3.333 & 1.215 & 0.040 \\
\hline BJCM-4 & 1.036 & 0.049 & 4.730 & 1.21 & 0.057 \\
\hline Mean \pm SD & & $0.063 \pm 0.044$ & $6.138 \pm 4.384$ & $2.51 \pm 1.265$ & $0.136 \pm 0.070$ \\
\hline
\end{tabular}


PhytOC content on a dry weight basis is correlated with the occluded carbon of phytoliths $\left(P<0.01, R^{2}=0.434\right)$.

\section{Discussion}

\subsection{Phytoliths and PhytOC}

Plants have different abilities to yield phytoliths. In general, angiosperms accumulate more phytoliths in their shoots than gymnosperms. Within the angiosperms, the Poaceae accumulate more phytoliths than other monocot species [41]. Whether different plants yield differing amounts of PhytOC, and what factors control this in each remain to be found. To answer the former question is beyond the scope of this paper. However, our analysis indicates that there is no significant correlation between phytolith yield and percentage PhytOC content on a dry weight basis in eight species of millet $\left(P=0.071, R^{2}=0.105\right)$, but the percentage PhytOC content on a dry weight basis is correlated with the occluded carbon of phytoliths $\left(P<0.01, R^{2}=0.434\right)$. Studies on wheat phytoliths have also demonstrated that there was no relationship between phytolith yield and percentage PhytOC content on a dry weight basis $\left(P=0.047, R^{2}=0.075\right)$ and a strong correlation also existed between percentage PhytOC content on a dry weight basis and the occluded carbon content of the phytoliths themselves [42]. These results all show that percentage PhytOC content on a dry weight basis is not determined by phytolith yield, but by the efficiency of carbon trapping during the phytolith's deposition in plant [19].

In other work, phytoliths could not be decomposed by using conventional methods of measuring soil carbon such as dry combustion and wet oxidation $[43,44]$. The occluded carbon in phytoliths therefore could not be determined and thus this carbon fraction was not included as a part of the total soil organic carbon pool. Also, previous studies have determined PhytOC using electron probes [45] — it is not an appropriate method for measuring PhytOC because the results only represent a small area bombarded by an electron beam. This is a likely reason why some data shows PhytOC can vary by up to $30 \%$ for some plants. In this study PhytOC was determined by elemental analyzer which combusted samples at $1000^{\circ} \mathrm{C}$. Phytoliths then decomposed and released the occluded carbon.

\subsection{Carbon sequestrated by PhytOC of millet}

Common millet and foxtail millet are important crops in arid and semi-arid regions of eastern Asia [46]. They were the earliest domesticated crops in the middle reaches of the Yellow River [47] and are still staple foods for these regions of Northern China. These two species of millets usually have an overlapping distribution because of similar physiological characters [48]. The total planting area for foxtail millet was 838900 ha in 2007 [49]. Common millet has an annual production of 1.5 million tonnes and the planting area is $1 \times 10^{6}$ ha $[50,51]$.

Dry biomass is a key factor for estimating phytolith carbon sequestration rate. However, not many studies have obtained the dry biomass of foxtail millet and common millet, and only grain production data are available. The ratio of grain to straw (grain/straw) has been widely applied to estimate the above-ground biomass of crops [52,53]. In this study, we used this ratio to estimate the straw weight and then obtain dry biomass weight.

Based on the harvest data of crops from 300 agricultural experimental stations in China, the mean value of grain/ straw for foxtail millet which was found to be 0.62 [54]. We analyzed 442 species of common millets from China and found that the mean value of grain/straw was 0.58 [55]. The mean annual production of foxtail millet and common millet were $1.83 \mathrm{t} \mathrm{ha}^{-1} \mathrm{a}^{-1}$ and $1.5 \mathrm{t} \mathrm{ha}^{-1} \mathrm{a}^{-1}$ during 1999 to 2008 , respectively [49,51]. These results show that the PhytOC accumulation rate of foxtail millet was $0.023 \pm 0.015 \mathrm{t} \mathrm{ha}^{-1} \mathrm{a}^{-1}$. In contrast to Foxtail millet, the PhytOC of common millet could sequester carbon at a rate of $0.020 \pm 0.010 \mathrm{t} \mathrm{ha}^{-1} \mathrm{a}^{-1}$. Compared with sugarcane, the phytolith carbon sequestration rate $\left(0.12-0.36 \mathrm{t} \mathrm{CO}_{2} \mathrm{ha}^{-1} \mathrm{a}^{-1}\right)$, of millets was rather low. This could be attributed to (1) millet phytoliths encapsulating less carbon than sugarcane and (2) millets yielding less dry biomass than sugarcane.

Recently, soil phytoliths from a typical stratigraphy of volcanic ash and paleosols at the Numundo sites in Papua New Guinea were examined [16]. Here it was found that the proportion of PhytOC to total carbon increased dramatically from less than $10 \%$ in the youngest layers to $82 \%$ in the older layers (Figure 2), which means that the accumulation of PhytOC in soil is a long-term sequestration. Assuming the highest PhytOC to dry biomass ratio $(0.214 \%)$ and using the annual production of foxtail millet during 1949 to 2008 (http://www.sannong.gov.cn), we can estimate the highest PhytOC sequestration in the last 60 years (Figure 3). The results showed that $7 \times 10^{6} \mathrm{t} \mathrm{CO}_{2}$ are likely to have been sequestered and this would be sufficient to offset $\mathrm{CO}_{2}$ emission released by the combustion of $2.69 \times 10^{6} \mathrm{t}$ standard coal. The PhytOC sequestration of foxtail millet generally declined during 1949 to 2008 in conjunction with changes in its planting area. However, other PhytOC crops such as wheat can capture more $\mathrm{CO}_{2}$ from the atmosphere and securely sequester it for a long time too.

Dry farming occurs on $48 \%$ of the $130 \times 10^{6}$ ha of arable land in China [56,57]. If all dry farming crops have a similar PhytOC accumulation rate as millets, this would lead to 2.37 $\times 10^{6} \mathrm{t} \mathrm{CO}_{2}$ being sequestered per year. Although phytoliths can occlude some organic carbon [58], the significant contribution of PhytOC to the carbon cycle has been ignored during the last half-century. Fully understanding the mechanisms of how Phytoliths occlude carbon and the PhytOC content in different plants would enable us to accurately estimate global phytolith accumulation rate. 


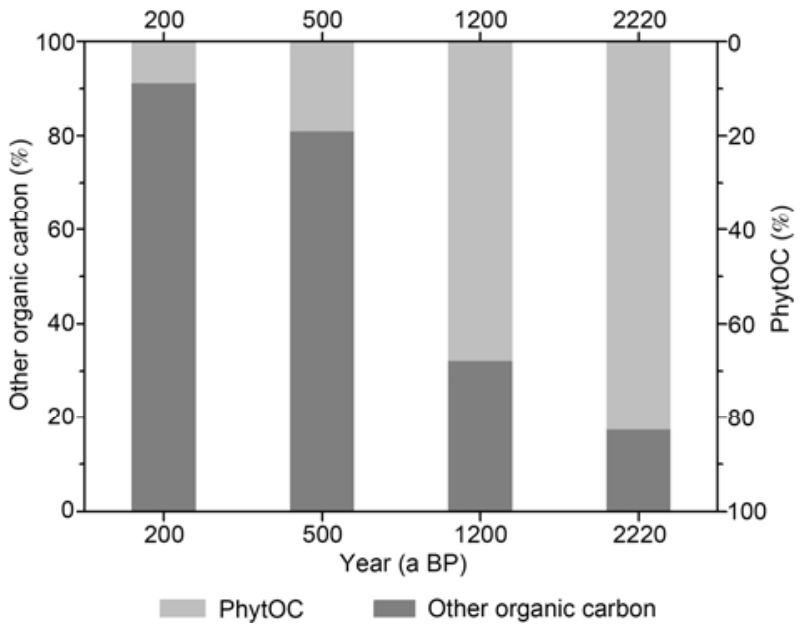

Figure 2 Comparison of soil PhytOC to soil organic carbon in Numundo, Papua New Guinea [16].

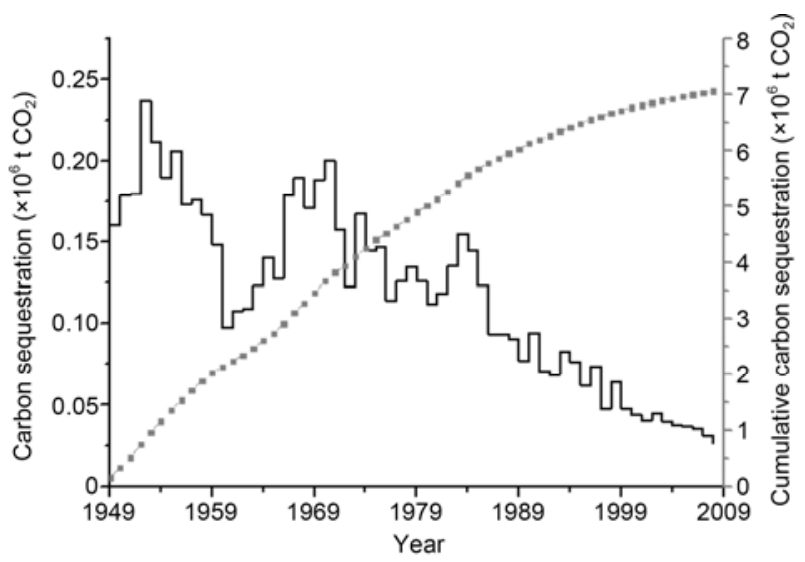

Figure 3 PhytOC accumulation rate of foxtail millet during 1949 to 2008.

\section{Conclusions}

Previous studies have argued that crops contribute less to carbon sink because they readily decomposed and quickly release $\mathrm{CO}_{2}$ back to the atmosphere. However, our study shows crops could sequester a substantial amount of carbon through the PhytOC fraction. The PhytOC carbon sequestration rate in Chinese common millet and foxtail millet were approximately $0.020 \pm 0.010$ and $0.023 \pm 0.015 \mathrm{t} \mathrm{CO}_{2} \mathrm{ha}^{-1} \mathrm{a}^{-1}$, respectively. Assuming a similar PhytOC accumulation rate as common millet for other crops, unirrigated Chinese farming systems could sequester $2.37 \times 10^{6} \mathrm{t} \mathrm{CO}_{2}$ per year. From 1949 to 2008 , about $7 \times 10^{6} \mathrm{t} \mathrm{CO}_{2}$ may have been sequestered by the PhytOC pool of foxtail millet. Agricultural activities have a complicated interaction with the global carbon balance. However, current studies on terrestrial ecosystem carbon sinks pay little attention to carbon sequestration by the PhytOC pool which has been poorly integrated into our current understanding of the carbon cycle. The potential of PhytOC sequestration provides a new approach for enhancing the soil organic carbon sink. More studies on the PhytOC of different crops are needed and this carbon fraction should now be incorporated in future long-term global carbon sequestration estimates.

We thank two anonymous reviewers and Professor Wu Haibin for their insightful and valuable comments that significantly improved the manuscript. Also thanks go to Professors Jin Guiyun and Tian Wanhua for collecting two species of millet and Wu Wenxiang for providing the annual production of foxtail millet. John A. Carter and Jeffrey F. Parr are thanked for their discussions about extraction of the phytoliths. This work was supported by the Strategic Priority Research Program of the Chinese Academy of Sciences (XDA05130602) and the National Natural Science Foundation of China (4107113).

1 Falkowski P, Scholes R J, Boyle E, et al. The global carbon cycle: A test of our knowledge of earth as a system. Science, 2000, 290: 291-296

2 Schimel D. Terrestrial ecosystems and the carbon cycle. Glob Change Biol, 1995, 1: 77-91

3 Kosten S, Roland F, Da Motta Marques D M L, et al. Climate-dependent $\mathrm{CO}_{2}$ emissions from lakes. Glob Biogeochem Cycles, 2010, 24: GB2007

4 Post W, Peng T, Emanuel W, et al. The global carbon cycle. Amer Sci, 1990, 78: 310-326

5 Gifford R. The global carbon cycle: A viewpoint on the missing sink. Funct Plant Biol, 1994, 21: 1-15

6 Houghton R A, Davidson E A,Woodwell G M. Missing sinks, feedbacks, and understanding the role of terrestrial ecosystems in the global carbon balance. Glob Biogeochem Cycles, 1998, 12: 25-34

7 Field C B. Plant physiology of the "Missing" carbon sink. Plant Physiol, 2001, 125: 25-28

8 Clark D A. Are tropical forests an important carbon sink? Reanalysis of the long-term plot data. Ecol Appl, 2002, 12: 3-7

9 Pacala S W, Hurtt G C, Baker D, et al. Consistent land- and atmosphere-based U.S. carbon sink estimates. Science, 2001, 292: 2316-2320

10 Siegenthaler U, Sarmiento J L. Atmospheric carbon dioxide and the ocean. Nature, 1993, 365: 119-125

11 Fang J Y, Guo Z D. Looking for missing carbon sinks from terrestrial ecosystem (in Chinese). Chin J Nat, 2007, 29: 1-6

12 Harrison K, Broecker W, Bonani G. A strategy for estimating the impact of $\mathrm{CO}_{2}$ fertilization on soil carbon storage. Glob Biogeochem Cycles, 1993, 7: 69-80

13 Fang J Y, Piao S L, Zhao S Q. The carbon sink:the role of the middle and high attitudes terrestrial ecosystem in the Northern Hemisphere (in Chinese). Acta Phytoecol Sin, 2001, 25: 594-602

14 Rovner I. Plant opal phytolith analysis: Major advances in archaeobotanical research. In: Schiffer M B, ed. Advances in Archaeological Method and Theory Vol.6. New York: Academic Press, 1983. 225-266

15 Piperno D. Phytoliths: A Comprehensive Guide for Archaeologists and Paleoecologists. London: Altamira Press, 2006. 5-21

16 Parr J F, Sullivan L A. Soil carbon sequestration in phytoliths. Soil Biol Biochem, 2005, 37: 117-124

17 Strömberg C. Using phytolith assemblages to reconstruct the origin and spread of grass-dominated habitats in the great plains of North America during the late Eocene to early Miocene. Paleogeogr Paleoclimatol Paleoecol, 2004, 207: 239-275

18 Prasad V, Strömberg C, Alimohammadian H, et al. Dinosaur coprolites and the early evolution of grasses and grazers. Science, 2005, 310: 1177

19 Parr J, Sullivan L, Chen B, et al. Carbon bio-sequestration within the phytoliths of economic bamboo species. Glob Change Biol, 2010, 16: 2661-2667

20 Grace J. Understanding and managing the global carbon cycle. J Ecol, 2004, 92: 189-202

21 Oldenburg C M, Torn M S, DeAngelis K M, et al. Biologically enhanced carbon sequestration: Research needs and opportunities. 
Report on the Energy Biosciences Institute Workshop on Biologically Enhanced Carbon Sequestration, 2008

22 Jones R L, Beavers A H. Aspects of catenary and depth distribution of opal phytoliths in Illinois soils. Soil Sci Soc Amer J, 1964, 28: 413-416

23 Wilding L P, Brown R E, Holowaychuk N. Accessibility and properties of occluded carbon in biogenetic opal. Soil Sci, 1967, 103: 56-61

24 Mulholland S, Prior C. AMS radiocarbon dating of phytoliths. MASCA Res Pap Sci Archaeol, 1993, 10: 21-23

25 Smith F, Anderson K, Meunier J, et al. Characterization of organic compounds in phytoliths: Improving the resolving power of phytolith $\delta^{13} \mathrm{C}$ as a tool for paleoecological reconstruction of $\mathrm{C} 3$ and $\mathrm{C} 4$ grasses. In: Meunier J D, Colin F, eds. Phytoliths: Applications in Earth Sciences and Hunman History. Netherlands: A.A. Balkema, 2001.317-327

26 Carter J A. Phytolith analysis and paleoenvironmental reconstruction from Lake Poukawa Core, Hawkes Bay, New Zealand. Glob Planet Change, 2002, 33: 257-267

27 Lu H Y, Wu N Q, Yang X D, et al. Phytoliths as quantitative indicators for the reconstruction of past environmental conditions in China I: Phytolith-based transfer functions. Quat Sci Rev, 2006, 25: 945-959

28 Bremond L, Alexandre A, Wooller M J, et al. Phytolith indices as proxies of grass subfamilies on East African tropical mountains. Glob Planet Change, 2008, 61: 209-224

29 Ge Y, Jie D M, Guo J X, et al. Response of phytoliths in Leymus chinensis to the simulation of elevated global $\mathrm{CO}_{2}$ concentrations in Songnen Grassland, China. Chinese Sci Bull, 2010, 55: 3703-3708

30 Lu H, Zhang J, Wu N, et al. Phytoliths Analysis for the discrimination of Foxtail Millet (Setaria italica) and Common Millet (Panicum miliaceum). PLoS ONE, 2009, 4: e4448

31 Ranere A J, Piperno D R, Holst I, et al. The cultural and chronological context of early Holocene maize and squash domestication in the Central Balsas River Valley, Mexico. Proc Natl Acad Sci USA, 2009, 106: 5014-5018

32 Li X Q, Zhou X Y, Zhang H B, et al. The record of cultivated rice from archaeobiological evidence in northwestern China 5000 years ago. Chinese Sci Bull, 2007, 52: 1372-1378

33 Kelly E F, Amundson R G, Marino B D, et al. Stable isotope ratios of carbon in phytoliths as a quantitative method of monitoring vegetation and climate change. Quat Res, 1991, 35: 222-233

34 Krull E S, Skjemstad J O, Graetz D, et al. ${ }^{13} \mathrm{C}$-depleted charcoal from $\mathrm{C} 4$ grasses and the role of occluded carbon in phytoliths. Org Geochem, 2003, 34: 1337-1352

35 Lü H, Wang Y, Wang G, et al. Analysis of carbon isotope in phytoliths from C3 and C4 plants and modern soils. Chinese Sci Bull, 2000, 45: $1804-1808$

36 Blackman E. Observations on the development of the silica cells of the leaf sheath of wheat (Triticum aestivum). Can J Bot, 1969, 47: 827-838

37 Piperno D. Phytolith Analysis: An Archaeological and Geological Perspective. San Diego: Academic Press, 1988. 43-44

38 Parr J, Sullivan L, Quirk R. Sugarcane phytoliths: Encapsulation and sequestration of a long-lived carbon fraction. Sugar Tech, 2009, 11: 17-21

39 Fang J Y, Guo Z D, Piao S L, et al. Terrestrial vegetation carbon sinks in China, 1981-2000. Sci China Ser D-Earth Sci, 2007, 50: 1341-1350

40 Wang Y J, Lu H Y. The Study of Phytolith and Its Application (in Chinese). Beijing: China Ocean Press, 1993. 37-43

41 Hodson M J, White P J, Mead A, et al. Phylogenetic variation in the silicon composition of plants. Ann Bot, 2005, 96: 1027-1046

42 Parr J, Sullivan L. Phytolith occluded carbon and silica variability in wheat cultivars. Plant Soil, 2011, 342: 165-171

43 Kerven G, Menzies N, Geyer M. Soil carbon determination by high temperature combustion: A comparison with dichromate oxidation procedures and the influence of charcoal and carbonate carbon on the measured value. Commun Soil Sci Plant Anal, 2000, 31: 1935-1939

44 Chatterjee A, Lal R, Wielopolski L, et al. Evaluation of different soil carbon determination methods. Crit Rev Plant Sci, 2009, 28: 164-178

45 Wang Y J. A study on the chemical compostion of phytolths (in Chinese). J Oceano Huanghai Bohai Seas, 1998, 16: 33-38

46 Lu H, Zhang J, Liu K-B, et al. Earliest domestication of Common millet (Panicum miliaceum) in East Asia extended to 10000 years ago. Proc Natl Acad Sci USA, 2009, 106: 7367-7372

47 Chen W H. Agricultural Archaeology (in Chinese). Beijing: Cultural Press, 2002. 42-48

48 You X L. Chinese Agricultural History (in Chinese). Beijing: China Agricultural Press, 2008. 162-173

49 Chen X H. The Statistical Data of Chinese Agriculture (in Chinese). Beijing: China Agricultural Press, 2009. 1-236

50 Chai Y, Wan F S. A Report for Developing Strategies of Minor Grain Crops in China (in Chinese). Beijing: China Agricultural Science and Technology Press, 2007. 37-53

51 Wei Y H. Distribution, production and scientific research survey of bromcorn millet in China. In: Wei Y H, Wang X Y, Chai Y, eds. Chinese Common Millet (in Chinese). Beijing: China Agricultural Press, 1990. 6-11

52 Anthoni P, Freibauer A, Kolle O, et al. Winter wheat carbon exchange in Thuringia, Germany. Agriculp Forest Meteorol, 2004, 121: 55-67

53 Zhang $\mathrm{W}$ J, Wang X J, Xu M G, et al. Soil organic carbon dynamics under long-term fertilizations in arable land of northern China. Biogeosciences, 2010, 7: 409-425

54 Zhang F C, Zhu Z H. Harvest index for various crops in China (in Chinese). Sci Agricul Sin, 1990, 23: 83-87

55 Wang X Y, Wei Y H. Chinese Contents of Common Millet (in Chinese). Beijing: China Agricultural Press, 1990. 1-302

56 National Bureau of Statistics of China. China Statistical Yearbook: 2006 (in Chinese). Beijing: China Statistics Press, 2006

57 Gao Z L, Feng X P, Peng K S. Study on the dry land agriculture of north part of China and its sustainable development (in Chinese). Ecol Econ, 2005. 91-94

58 Jones L, Milne A, Wadham S. Studies of silica in the oat plant. Plant Soil, 1963, 18: 358-371

Open Access This article is distributed under the terms of the Creative Commons Attribution License which permits any use, distribution, and reproduction in any medium, provided the original author(s) and source are credited. 